https://doi.org/10.52676/1729-7885-2021-1-82-84

УДК 533.9.082

\title{
EXPERIMENTAL STUDY OF THE MECHANISM EROSION MATERIALS EXPOSED TO LOW PLASMA POWER FLOWS
}

\author{
1) Zh.M. Moldabekov, ${ }^{1)}$ A.M. Zhukeshov, ${ }^{2)}$ V.Ya. Nikullin, ${ }^{2)}$ A.A. Ereskin, ${ }^{1)}$ A.T. Gabdullina, ${ }^{1)}$ A.U. Amrenova \\ 1) al-Farabi Kazakh National University, Almaty, Kazakhstan \\ 2) P.N. Lebedev Physical Institute of Russian Academy of Sciences, Moscow, Russia
}

In this paper, a low activation of ferritic-austentic steel was studied when it was exposed with plasma. The experiment was carried out on a plasma focus device with energy of $1.9 \mathrm{~kJ}$, with a pressure of 2.5 torr of deuterium. AFM analysis shows that cracks up to 2 microns and holes from 81 to $281 \mathrm{~nm}$ are found on steel surfaces. The mechanism of the occurrence of erosion of low-activation ferritic-austentic steel is also indicated. It is established that the mechanism of erosion depends on the momentum.

Keywords: plasma surface, cracks, droplet ejection, erosion, irradiation materials.

\section{INTRODUCTION}

One of the most important tasks of plasma physics [1] is to study the resistance of materials of the first wall, the divertor and other nodes of the thermonuclear reactor to stationary plasma-thermal effects with a capacity of up to $20 \mathrm{~mW} / \mathrm{m}^{2}$ and intense pulsed duration of $0.1-10 \mathrm{~ms}$ and a power of $1-10 \mathrm{GW} / \mathrm{m}^{2}$ [1-3]. Many of the basic problems investigated and solved but one of the main problems still not enough investigated is connected with material science and radiation nuclear physics [1-12]. They are long lasting irradiation and heat loads that are generated in the fusion devices affect the construction materials and appearance different of defects on the surface materials. After long lasting radiations it leads to erosion of the protective coatings of the divertor and the first wall of the thermonuclear reactor [5].

In $[3,8]$ work showed that stainless steels were developed to reduce the ability to be activated by neutrons and plasma. Also, the important note of the work is connected with the fact that tungsten is plasma-facing material in ITER, whereas ferritic-martensitic steels are used as plasma-facing materials in thermonuclear devices and intended for structural components of ITER. Furthermore, these steels may be more perspective for use in the following modern generation of nuclear fusion devices of both types - with inertial and magnetic plasma confinement. Austenitic steels are utilized in working chambers of these devices.

Macroscopic erosion, characterized by lower specific energy values, is more dangerous than evaporation and sputtering [4-6]. In the case of all metals, including austenitic steels resulting from plasma exposure lead to the formation of cracks, deterioration of thermal conductivity, and the release of particles of matter into the vacuum chamber [7]. In [6-7] were shown that the main factor leading to damage to materials under the influence of plasma is thermal loads that lead to melting of the irradiated surface layers, erosion of materials (loss of mass during evaporation), the formation of various types of surface defects and micro cracks.
To clarify the physical process of the interaction of intense plasma flows with protective materials and obtain vital experimental data, it is impossible to construct and verify computational and theoretical models of the phenomena occurring. It is necessary to conduct model experiments. This paper will consider the formation of different types of damage to the surface of materials when irradiated with pulsed plasma flows of high power and shows that this can cause deep erosion of the material, the most dangerous at relatively low power flows.

\section{EXPERIMENTAL SETUP AND METHOD \\ OF INVESTIGATION}

Dense Plasma Focus device may be suitable for fusion first wall studies and its related material researches. As is well-known plasma focus devices are sources of high energy ions [6], electrons, x-rays and neutrons [78 ] and intense bursts of fast plasma streams. The experimental work irradiation of specimens was carried out using PF-4 device which cylindrical coaxial electrodes: anode and cathode (length of anode and cathode $33 \mathrm{~mm}$ and $38 \mathrm{~mm}$ respectively) [2,4]. The insulator used is a $31 \mathrm{~mm}$ long ceramic. The energy storage system of the PF-4 includes a capacitor bank of capacitance $20 \mu \mathrm{F}$ with a working voltage of $10-20 \mathrm{kV}$ and $2.6-280 \mathrm{nH}$. High voltage is switched using a controllable discharger (airfilled). The results in this work were obtained by charging the capacitor bank at $14-18 \mathrm{kV}$. Deuterium was used as the working gas at a pressure of about 1-3 torr.

As specimens were used flat square plates of $10 \times 10 \mathrm{~mm}$ size made of $10 \mathrm{Cr} 12 \mathrm{Mn} 20 \mathrm{~W}$ stainless steel. To eliminate edge effects, sample sizes were chosen so that they completely blocked the plasma flow. The thermal load Q in each sample was gradually increased from 50 to $230 \mathrm{~J} / \mathrm{cm}^{2}$. Irradiation of targets was carried out with a normal fall of the plasma flow to the surface. To adjust the experiment after each impact the sample target was removed from the working chamber setup for measurement of mass loss and analysis by atomic force microscopy (AFM), x-ray analysis (RSA) and scanning electron microscopy (SEM). 


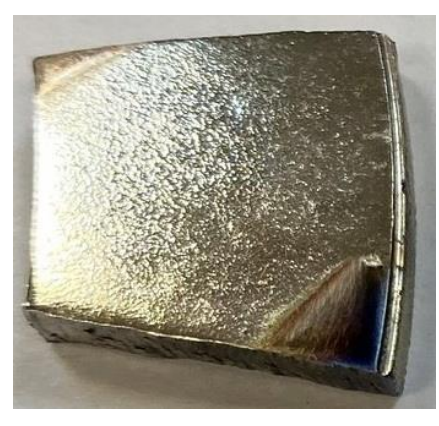

a)

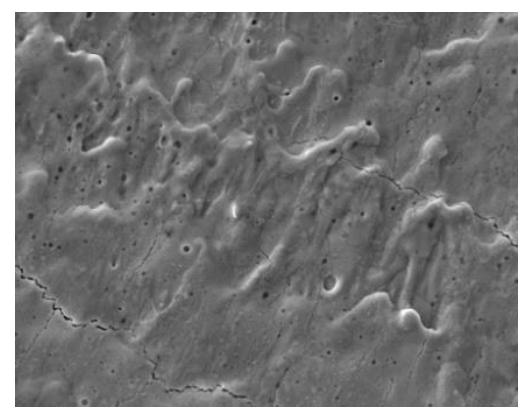

d)

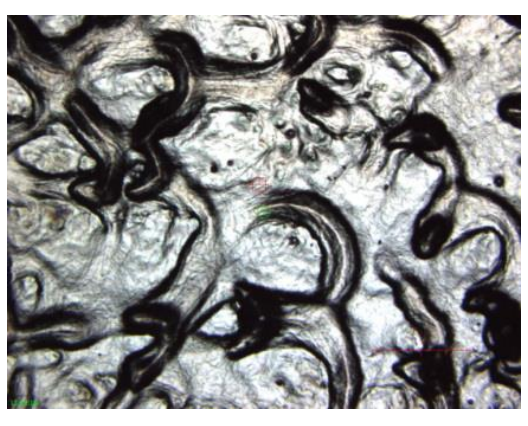

b)

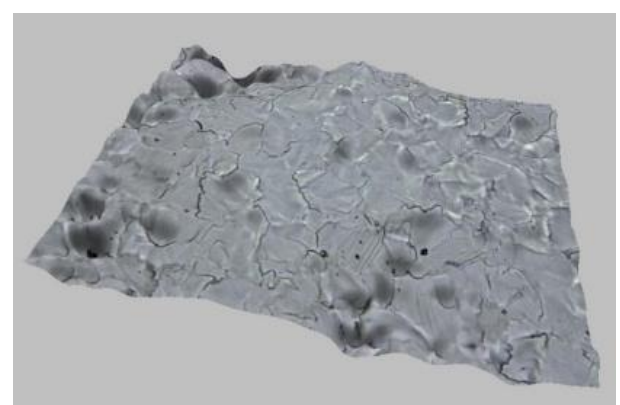

c)

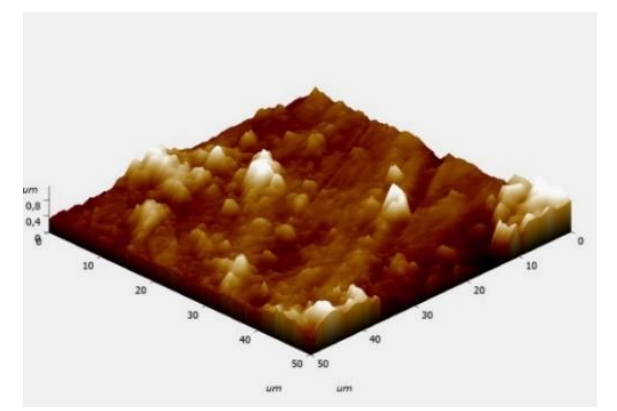

e)

\section{RESULTS AND DISCUSSION}

Erosion studies of materials in middle-power pulsed discharges have been completed. In figure present electron photos of irradiated surfaces of the steels obtained using the scanning electron and atom force microscope. They contain the following defects: mainly melting, pores, droplets and spots of copper redeposited from the DPF anode (b, c). After irradiation surface of the specimens formed wave-like relief, resulting in process remelting, evaporation and sputtering etc. [10, 12, 13]. Analysis of the surface materials shows that erosion of the melt layer occurs mainly due to two erosion mechanisms: due to the ejection of metal drops from the target surface and due to the movement of the melt along the target surface.

The macroscopic mechanism of erosion materials which occur droplet ejection might be determined by weighting and reducing the specimen thickness of the targets before and after the plasma exposure. The results of weighing the steel specimens and a calculation of the layer thickness $d$ evaporated before and after plasma irradiations presents in table. Melt motion leads to displacement of the material along the surface and this mechanism might be analyzed through the measurement of the surface specimens by SEM. As shown in figure $(\mathrm{d}, \mathrm{e})$ formed $5 \mu \mathrm{m}$ to $10 \mu \mathrm{m}$ micro-cracks and from $81 \mathrm{~nm}$ to $281 \mathrm{~nm}$ holes. Analysis showed that the different kind of damaged material surface depending on the number of plasma impulse, the power flux density of the radiation and thermal properties of the target material.
Table. Results of mass weighing of specimens under irradiation

\begin{tabular}{|c|c|c|c|c|c|}
\hline $\begin{array}{c}\text { Target } \\
\text { sam- } \\
\text { ple }\end{array}$ & $\begin{array}{c}\text { Target } \\
\text { distance } \\
\text { from ano- } \\
\text { de, } \mathrm{nm}\end{array}$ & $\begin{array}{c}\text { Number } \\
\text { of shots }\end{array}$ & $\begin{array}{c}\text { Total } \\
\text { mass } \\
\text { loss } \Delta \mathrm{m}, \\
\mathrm{mg}\end{array}$ & $\begin{array}{c}\text { Mass loss } \\
\text { per pulse, } \\
\mathrm{mg}\end{array}$ & $\begin{array}{c}\text { Thickness of } \\
\text { evaporated } \\
\text { layer per one } \\
\text { pulse } \mathbf{d}, \boldsymbol{\mu m}\end{array}$ \\
\hline 1 & 60 & 10 & $\approx 0.53$ & 0.052 & 0.56 \\
\hline 2 & 60 & 20 & $\approx 1.1064$ & 0.055 & 0.67 \\
\hline 3 & 60 & 30 & $\approx 1.83$ & 0.061 & 0.78 \\
\hline
\end{tabular}

\section{CONCLUSION}

The analysis shows that at specific parameters, the plasma action leads to the destruction of materials. The dominant mechanism of destruction of materials is a macroscopic mechanism that causes the entrainment of matter by fragments and drops, the accumulation of cracks in the material, changes in the surface relief and an increase in the rate of evaporation and melting. Information on the macroscopic erosion of materials will be used in the future to build computational models that allow predicting the erosion rate, as well as the amount and composition of erosion products in a tokamak with reactor parameters. 


\section{REFERENCES}

1. ITER Physics Basis. - Nuclear Fusion. - 1999. - Vol. 39. - P. 2137.

2. S.N. Polukhin, A.E. Gurei, V.Ya. Nikulin, E.N. Peregedova, P.V. Silin. Issledovanie mechanisma generaciy plasmenniyh struiy v plasmennom fokuse // Plasma physics. - 2020. - Vol. 46, No. 2, - P. 99-109. (in Russian)

3. Pimenov, V.N. et al. Damage and modification of materials produced by pulsed ion and plasma streams in Dense Plasma Focus device. Nukleonika. - 2008. Vol. 53 (3). P. 111-121.

4. Mayorov A.N., Nikulin V.Y., Oginov A.V., Zhukeshov A.M. Study of axial plasma flows in the PF-4 plasma focustype setup // Bulletin of the Lebedev Physics Institute. 2015. - Vol. 42, No. 7. - P. 193-200.

5. Van der Laan J.G., Akiba M., Hassanein A. et al. - Fusion Engineering and Design, 1991. - Vol. 18. - P. 135.

6. S.H. Saw, V. Damideh, Jalil Ali, R.S. Rawat, P. Lee, S. Lee, Damage Study of Irradiated Tungsten using fast focus mode of a $2.2 \mathrm{~kJ}$ plasma focus. Vacuum. - 2017. Vol. 144. P. 14-20.

7. S. Lee, S.H. Saw. Plasma focus ion beam fluence and flux for various gases. - Phys. Plasmas. - 2013. Vol. 20 (062702).

8. Baluc, N., Schäublin, R., Spätig, P., Victoria, M. On the potentiality of using ferritic/martensitic steels as structural materials for fusion reactors. Nucl. Fusion. - 2004. Vol. 44. - P. 56-61.
9. Zhukeshov A.M., Moldabekov Zh., Gabdullina A.T., Amrenova A.U., Serik K. Experiments in the plasma focus "PF-30"-energy absorption and damage evolution on plasma facing $/ / 20^{\text {th }}$ International Conference on Radiation Effects in Insulators, Nur-Sultan (Kazakhstan), 2019. - P. 147.

10. Zhukeshov A., Nikulin V., Gabdullina A., Amrenova A., Mukhamedryskyzy M., Moldabekov Z. The pulse plasma flows application in material science and nanotechnology //Abstract book of Advanced application on plasma physic, Saint-Petersburg (Russia). - 2019. - P. 93.

11. Ivanov L.I., Pimenov V.N., Maslyaev S.A. et al. Influence of dense deuterium plasma pulses on materials in Plasma Focus device. Nukleonika. -2000. - Vol. 45, No. 3. P. 203-207.

12. O.V Ogorodnikova. Fundamental aspects of deuterium retention in tungsten at high flux plasma exposure. Journal of Applied Physics. -2015. - Vol. 118 (074902). https://doi.org/10.1063/1.4928407

13. Xiaolong Jiang, Ying Liu, Bilali Muhutijiang, Zhengkun Liu, Keqiang Qiu, Xiangdong Xu, Yilin Hong, Shaojun Fu, Investigation on morphology and evolution process of plasma induced pitting damage during the ICP etching of fused silica, Vacuum, 2016. - Vol. 12. - P. 121-125.

\title{
ПЛАЗМА АҒЫНДАРЫМЕН ӘСЕРЛЕСКЕН КЕЗДЕГІ МАТЕРИАЛДАРДЫҢ ЭРОЗИЯСЫНЫН МЕХАНИЗМІН ЭКСПЕРИМЕНТТІ ЗЕРТТЕУ
}

\author{
1) Ж.М. Молдабеков, ${ }^{1)}$ А.М. Жукешов, ${ }^{2)}$ В.Я. Никуллин, ${ }^{2)}$ А.А. Ерескин, ${ }^{1)}$ А.Т. Габдуллина, ${ }^{1)}$ А.У. Амренова \\ 1) әл-Фараби атындавы Қазақ Ұлттық университеті, Алматы, Қазақстан \\ 2) Ресей әылым академиясының П.Н. Лебедев атындагы физика институты, Москеу, Ресей
}

Аталған жұмыста төмен белсендірілген феррит-мартенситті болаттың плазма ағындарымен әсерлесуі зерттелді. Эксперимент энергетикасы 1,9 кДж болатын плазмалық қондырғысында 2,5 торр дейтерии газ қысымында жүргізілді. Атомдық күштік микроскоптық талдау нәтижелері болаттың бетінде 2 мкм дейінгі сызаттар және 81-280 мкм дейінгі тесіктер пайда болғанын көрсетті. Сонымен қатар төмен белсендірілген феррит-мартенситті болат бетіндегі эрозияның пайда болу механизмі көрсетілді. Пайда болған эрозиялық механизм плазма ағындарының импульсына тәуелділігі көрсетілді.

Түйін сөздер: плазмалық фокус, сызаттар, тамшылық лақтырулар, эрозия, материалдардың сәулеленуі.

\section{ЭКСПЕРИМЕНТАЛЬНОЕ ИССЛЕДОВАНИЕ МЕХАНИЗМА ЭРОЗИИ МАТЕРИАЛОВ ПРИ ВОЗДЕЙСТВИИ ПОТОКОВ ПЛАЗМЫ}

\author{
1) Молдабеков Ж.М., ${ }^{1)}$ Жукешов А.М., ${ }^{2)}$ Никуллин В.Я., ${ }^{2)}$ Ерескин А.А., ${ }^{1)}$ Габдуллина А.Т., ${ }^{1)}$ Амренова А.У. \\ 1) Казахский национальный университет им. аль-Фараби, Алматы, Казахстан \\ 2) Физический институт им. П. Н. Лебедева Российской академии наук, Москва, Россия
}

В данной работе исследовано воздействие плазмы на образцы ферритно-мартенситной стали с низкой активацией. Эксперимент был проведен на установке «Плазменный фокус» при следующих параметрах плазменной обработки: $\mathrm{Q}=1,9$ кДж, при давлении $\mathrm{P}=2,5$ торр дейтерия. Анализ АСМ показывает, что после воздействия плазмы на стальных поверхностях обнаружены трещины длиной до 2 мкм и поры от 80 до 280 мкм. Также был исследован механизм развития эрозии в образцах ферритно-мартенситной стали с низкой активацией в зависимости от количества импульсов.

Ключевые слова: плазменный фокус, трещуины, выброс капель, эрозия, облучение материалов. 